\title{
Communicational Role of Mosques Architecture
}

\author{
Mandana Saniei (Corresponding author) \\ PhD Student, Social Communication Sciences, Department of Mass Communication \\ Faculty of Humanities and Social Sciences, Science and Research Branch \\ Islamic Azad University, Tehran, Iran \\ E-mail: Mandanasaniei@yahoo.com
}

Ali Delavar

Professor, Allameh Tabatabai University, Tehran, Iran

Received: September 23, $2011 \quad$ Accepted: September 30, $2011 \quad$ Published: March 1, 2012

doi:10.5539/ass.v8n3p137

URL: http://dx.doi.org/10.5539/ass.v8n3p137

\begin{abstract}
Artist architects have long considered prayers highly and everything associated with the prayer has meant sacred for them. Among these objects, people and places associated with the prayer, means even more to them. Especially, the mosque is not only a place for worship, but also a place for wondering in the creation philosophy and place of sanctum of man with God. This article is trying to study the communicational role of architecture of mosques.
\end{abstract}

Keywords: Mosque, Architecture, Communication, Man's communication with God

\section{Introduction}

Of all Muslim institutions, the mosque is the most important place for the public expression of Islamic religiosity and communal identity. A mosque is a physical manifestation of the public presence of Muslims and serves as a point of convergence for Islamic social and intellectual activity. The Arabic word for mosque is masjid, which means a "place of prostration" before God. Mosques are mentioned in the Qur'an, and the earliest model for a mosque was the residence that the prophet Muhammad built when he moved to Medina. This first mosque was an enclosure marked as a special place of worship. A small part of the mosque was sectioned off to house the Prophet and his family, and the remaining space was left open as a place for Muslims to pray.

Although later mosques developed into complex architectural structures built in diverse styles, the one requirement of all mosques continues to be based on the earliest model: a designation of space for the purpose of prayer. The early mosque served an equally important function that thousands of mosques continue to serve today: The mosque is a place where Muslims foster a collective identity through prayer and attend to their common concerns. A Muslim city typically has numerous mosques but only a few congregational or Friday mosques where the obligatory Friday noon prayers are performed.

As Islam spread outside Arabia, Islamic architecture was influenced by the various architectural styles of the conquered lands, and both simple and monumental mosques of striking beauty were built in cities of the Islamic world. Despite the borrowings from diverse civilizations, certain common features became characteristic of most mosques and thus serve to distinguish them from the sacred spaces of other religions and cultures (Note 1).

Islamic architecture has innovated special ornamentations, colors and engineering units which can be adopted anywhere. The triangle, square and circle for instance are facts because they comply with mental concepts. A new concept of unity has merged in Islamic architecture. It calls for unity as a base for life cycle.

This was reflected on intellectual aspects, art and architecture. Unity in Islamic architecture is not only determined by the engineering frequency pivot, but also by the vacuum at a particular point such as the Kaaba or the fountain in the mosque nave. Here, the dynamic power unifies parts and maintains their sovereignty to incorporate with the whole.

The principle of unity in Islamic architecture is applicable on horizontal projections as well as on radial star-shaped decorations and walls which surround the high gateway whose doors can be rectangular, pointed or circular. The 
charm of walls in Islamic architecture will be attained if aesthetic standards and sensible perceptions are met. Certain ornamental elements such as oriels, Muqarnasat (i.e. hive-shaped designs), sculptures and Arabic calligraphy which are inscribed on stones have contributed to the rise of a new architectural pattern (Jenkins, 2002).

The Prophet of Islam has built the first mosque on his way from Mecca to Medina (Forghani, 2003). Mosques are not only historically a center of worship of God, but have always had multiple uses. Education and dissemination of Islamic law, religious education and scientific literacy, conducting legal affairs, resolving disputes, conducting enforcement of the offenders, delivering fiery sermons, especially in crisis and war time for gathering Muslims and sending them to jihad against the enemies of Islam and taking the necessary measurements for better life of people, improving social conditions and handling the affairs of poor people have been of the functions of the mosque from its emergence up to nowadays.

In this respect, the design of a building surely considers the people who will use it. It may involve the number of people, their relationship, and how the people will use. As we see a building, we will get clues about the users or the people in the building. Reading a text can reveal the writer, to whom it is addressed, and the subject of person or parties it talks about, and the relationship among them. This gives an assumption that text and the architecture have participants to consider (Note 2).

So in this paper it is tried to deal with the communicational role of mosque architecture: the architecture of mosques and the human relationship with God, mosque as the connection between man's world and God and the features of the communicational role of mosque.

\section{Architecture Forms and Styles of mosques and buildings in Muslim countries}

Many forms of Islamic architecture have evolved in different regions of the Islamic world. Notable Islamic architectural types include the early Abbasid buildings, T-Type mosques, and the central-dome mosques of Anatolia. The oil-wealth of the 20th century drove a great deal of mosque construction using designs from leading modern architects.

Arab-plan or hypostyle mosques are the earliest type of mosques, pioneered under the Umayyad Dynasty. These mosques are square or rectangular in plan with an enclosed courtyard and a covered prayer hall. Historically, because of the warm Mediterranean and Middle Eastern climates, the courtyard served to accommodate the large number of worshippers during Friday prayers. Most early hypostyle mosques have flat roofs on top of prayer halls, necessitating the use of numerous columns and supports (Hillenbrand, R). One of the most notable hypostyle mosques is the Mezquita in Córdoba, Spain, as the building is supported by over 850 columns (Religious Architecture and Islamic Cultures, 2006). Frequently, hypostyle mosques have outer arcades so that visitors can enjoy some shade. Arab-plan mosques were constructed mostly under the Umayyad and Abbasid dynasties; subsequently, however, the simplicity of the Arab plan limited the opportunities for further development, and as a result, these mosques gradually fell out of popularity (Hillenbrand, R).

The Ottomans introduced central dome mosques in the 15th century and have a large dome centered over the prayer hall. In addition to having one large dome at the center, there are often smaller domes that exist off-center over the prayer hall or throughout the rest of the mosque, where prayer is not performed (Vocabulary of Islamic Architecture, 2005). This style was heavily influenced by the Byzantine religious architecture with its use of large central domes (Hillenbrand, R).

\section{Physical Elements of the Mosque Architecture}

The most important characteristic of a mosque is that it should be oriented toward Mecca. One or more niches (mihrab) on one of the walls of the mosque often serve as indicators of this direction, called qibla. When the imam leads the prayers he usually faces one of these niches. Next to the mihrab, a pulpit (minbar) is often provided for the delivery of sermons (khutba). Many mosques also have separate areas for performing ritual ablution, and separate sections for women. In many mosques, several rows of columns are used to mark the way for worshipers to line up behind the imam during prayer.

Mosques usually have one or more minarets, or towers, from which the muezzin calls Muslims to prayer five times a day. In addition to their functional use, these minarets have become distinguishing elements of mosque architecture. In large mosques in particular, minarets have the effect of tempering the enormity and magnificence of the domed structure by conveying to the viewer the elevation of divinity above the pretensions of human grandeur.

Most mosques also have a dome, and the line connecting the center of the dome to the niche is supposed to point toward Mecca. Throughout the world there are many mosques that are not actually directed toward Mecca, but 
such misalignment is due to inaccurate methods for determining the direction of Mecca and does not imply a disregard for this requirement. The mosque is not a self-contained unit, nor is it a symbolic microcosm of the universe, as are some places of worship in other religions. Rather, the mosque is always built as a connection with Mecca, the ultimate home of Muslim worship that metaphorically forms the center of all mosques.

The participants in the discourse and the physical form are human and God. The operation of the relation there covers the horizontal relation among the individuals, and the transcendental relation between the individual of human as creature in one side and God as the creator, in another. These operations are explored through analysis on the semiotics of architectural elements: form, partition, size, and the arrangement of interior and exterior properties. Thus, mosque with its distinctive design is actually a piece of discourse which tells a story among of which there is a fact about the participants and their relation mechanism, just like a written commonly does (Note 3).

Islamic architecture heavily depends on engineering and aesthetic principles. We should make it clear that Islamic architecture had originated and then its features were inferred accordingly. However, the religious aspect is the most distinctive feature to which Islamic architecture is indebted. It is represented in the Islamic aesthetic mentality.

Mosque has been the first house to be built on the basis of piety. Muslims congregate there under one dome yielding to and fearing of Allah. Consequently, architects have set a number of criteria that mosques should meet since the early age of Islam. These criteria include:

- communication among prayers

- having no columns in the mosque nave

- having no direct entrance into the nave

- having several openings for illumination.

Roman Architecture for instance influenced Islamic architecture particularly in the field of stone columns. This is a normal matter as it shows how dynamic and vital the architecture is. In fact, Islam urges its followers to communicate with other nations because static cultures will definitely die.

As a direct result for Islamic conquers in the Abbasid and Umayyad ages, there was a dire need for building forts and castles in cities. After that, Islamic architecture began influencing other civilizations. For example, Arabesque which was initiated by Muslim architects became very popular in Europe and Asia as it was the case in Spain, Sammerqand and Bukhara where it interacted with the indigenous arts. In China, mosques were built in harmony with local house roofs, entrances and construction materials. Later, fundamental features of mosque were introduced to other civilizations:

1). Much attention was paid to the minaret whose height reaches tens of meters and designs vary from circular to polygonal shapes. Some mosques have several minarets that can be used as beacons at night. It is worth mentioning that the designs and shapes of minarets reflect both the historical and spatial eras. Today, there are various designs of minarets in Central Asia, North Africa and Spain.

2). Dome: the first dome in Islam was built for the Holy Mosque of Jerusalem in 691 AD. Historically, the dome was first developed in Damascus in 706 AD.

3). Arch: its decorations and designs varied in the light of construction materials that were available in conquered states.

4). Columns: they are considered the most valuable architectural remains in mosques and buildings. At the early stages of mosque architecture, columns had been built by using the trunks of palm trees. Then, the industry of construction materials flourished, when stone and mud were used to build columns. As a matter of fact, the Greek and Roman architectures inspired Muslim architects to use stones as construction materials for building columns.

5). Muqarnasat: It stands for the hive-shaped decoration which dates back to the 11th century. Nowadays, its designs vary in accordance with the desired purpose and shape (Itewi, 2007).

\section{Communication Features of the Mosque}

Direct real, and deep contact with the audience, conveying knowledge and providing conditions for human excellence, its usability for the general public and effectiveness of mosques both on literate and on illiterate audiences, its being a sacred place, the accuracy and reliability of messaging to its audiences and its independence to power centers are of the mosque's communication features to name a few (Forghani, 2003).

The world's big cities generally host Islamic centers that enjoy broad cultural radiation. However, certain centers ensure only the mosque function. In addition, considering the diversity of the activities of the Islamic cultural 
centers and their religious, social and cultural roles, they are regarded as one of the main components of the Islamic cultural reality outside the Islamic world, thanks especially to the fact that they are generally managed and supervised by elite of highly qualified Muslim intellectuals. The cultural radiation of Islamic cultural centers is reflected among Muslim communities and minorities, on the one hand, and among interested non-Muslim citizens living in the neighboring areas, on the other, which is likely to redress the image of Islam by highlighting the true values and principles of this religion (ISESCO, 2009).

The mosque as an Islamic cultural center is a multi-faceted cultural institution which comprises communicational activities among Muslims. Therefore, the structure of the mosque has been emphasized in this strategy to put forward suggestions, procedures and initiatives to improve the quality of Islamic communication tools outside the Islamic world and their role in enlightening public opinion and guiding it to deal with the concerns of Muslims and Islam outside the Islamic world. Therefore, it is necessary to set up plans and programs to serve the universal message of Islam, to revive its eternal heritage and transmit it to the generations to come. This entails a good use of the human, financial and technical resources such as the building of mosques with highly elaborated structure and architecture.

The Islamic cultural centers outside the Islamic world strive to accomplish certain goals relating to Islamic Education and establishing links among Muslims so as to immunize their cultural identity and consolidate their sense of belonging and to motivate them to proceed according to what pleases God and benefits Muslims in their host communities. However, the geographical distance between the Islamic centers across the world has been a preventive factor against any coordination between the plans of cultural action adopted in those centers. This has led to discrepancies in the work methodologies of those centers and especially mosques, which precluded an accord on specifying priorities in the cultural field. The absence of a unified concept about the Islamic cultural problematic in host countries was one of the motivations behind laying down a strategy for Islamic cultural action outside the Islamic world. This Strategy would facilitate preparing a plan to unify the work methodologies among Islamic centers and Muslim leaders outside the Islamic world. It would also help centers develop their mission in the fields of education, information and communication, in conformity with modern discourse and the requirements of consolidating the sense of belonging among young Muslims in particular.

\section{The Relationship between the Mosque and the World}

It is one of the main components of the religious, social and cultural reality which contributes to cultural education, religious guidance and the establishment of solid relations of brotherhood between the different members of Muslim communities and minorities.

The mosque plays an important role in maintaining relations of coexistence in non-Muslim societies. It is a place of religious and cultural teaching and guidance which spans such various fields as interpersonal relations, ethics, principles of good neighborhood, respect of the other, religious tolerance and abstinence from wrongdoing. The authorities in non-Muslim countries are fully aware of the role played by the mosque in regulating the conduct of mosque goers, and strengthening attachment to virtue, values and good morals which contribute to reduce crime rates and delinquency.

In non-Muslim countries, the mosque is not only a place of worship but an academic center where conferences are given by resident or visiting intellectuals. Certain known mosques are managed by graduate people who see to promoting the educational and scientific role of the mosque, in such a way as to enrich and activate the Islamic cultural action outside the Islamic world.

However, the truth about building such a structure is taking the audience to some spiritual space with the language of arts which itself makes the audience to think and reach a deep knowledge (Seyedeinnia, 1998).

\section{Conclusion}

This paper reviewed the importance of architecture of the mosque emphasizing its communicational role. Studies have shown that the architecture of the mosque plays an important role in messaging cultural and religious knowledge to its audiences. Therefore, reconsidering the architecture of the mosques and supplying them with qualified managing staff to reinforce the communicational role of mosques and build integrity among Muslims as well as outside the Islamic world is of highest importance for enhancing the communication role of mosques and Islamic centers in the world for both disseminating the true image of Islam and its principles of tolerance and establishing friendly relations with foreign institutions and religious organizations having a moderate vision on Islam.

\section{References}

Forghani, Mahdi. (2003). Introduction to traditional communication in Iran, Tehran, Center for Media Studies. 
Hillenbrand, R. Masdjid. I. In the central Islamic lands, In P.J. Bearman, Th. Bianquis, C.E. Bosworth, E. van Donzel and W.P. Heinrichs. Encyclopaedia of Islam Online. Brill Academic Publishers.

Itewi, Mahmoud. (2007). Towards a Modern Theory of Islamic Architecture. Australian Journal of Basic and Applied Sciences, 1(2): 153-156.

Jenkins, Marilyn. (2002). Islamic Art and Architecture, 650-1250.

Publications of the Islamic Educational, Scientific and Cultural Organization -ISESCO Rabat- Morocco - 1430H/ 2009 A.D.

Religious Architecture and Islamic Cultures. Massachusetts Institute of Technology. [Online] Available: http://web.mit.edu/4.614/www/handout02.html (April 9, 2006)

Sydeinnnia, Mehdi. (1998). To Decode the Symbols in the Architecture and Decorations of Imam Mosque, Isfahan, Islamic Republic of Iran Broadcasting School, master's thesis, production trends.

Vocabulary of Islamic Architecture. Massachusetts Institute of Technology. The original on 2005-11-24. [Online] Available:

http://web.archive.org/web/20051124083425/http://ocw.mit.edu/OcwWeb/Architecture/4-614Religious-Architec ture-and-Islamic-CulturesFall2002/LectureNotes/detail/vocab-islam.htm\#islam6. (April 9, 2006)

\section{Notes}

Note 1. http://www.islamset.com/encyclo/mosque.html

Note 2. http://jurnal.ump.ac.id/index.php/leksika/article/download/33/31

Note 3. http://www.islamset.com/encyclo/mosque.html 